\title{
Discussion on the Impact of the E-Waste Dismantling on the Life of Chinese Residents
}

\author{
Ming Li \\ JiLin Business And Technology College, ChangChun ,China \\ 120857715@qq.com
}

Keywords: E-waste, Dismantling, Life of Residents

\begin{abstract}
Environmental problems caused by the e-waste dismantling have attracted widespread attention. According to the statistics from the United Nations Environment Programme (UNEP), $70 \%$ of global e-waste has entered into our country through a variety of ways, while China itself has generated lots of e-waste. China's e-waste disposal activities in more traditional technologies. This paper analyzed and summarized the pollution actualities of persistent toxic pollutants caused by China's e-waste disposal, management measures and regulations, persistent health risks associated with the exposure of toxic pollutants which are faced by residents from dismantling areas and the latest development of researches, and this paper also made a prospect.
\end{abstract}

\section{Introduction}

E-waste refers to electric and electronic products which can't be reused or have been discarded, including old mobile phones, computers, refrigerators, televisions, electric motors, transformers, and etc. With the development of global electronic technology, the replacement rate of electronic products also continues to accelerate, about 20-50 million tons of e-waste is generated each year, and annual growth rate continues to increase at about $4 \%$, E-waste become the world's fastest growing solid waste. The safe disposal processing of e-waste is complicated with a low degree of automation, Disposing e-waste safely has become a global problem. Non-standard dismantling and recycling have brought a negative impact on the environment and human health, and the serious environmental pollution caused by non-standard disposal of e-waste has become one of the hot spots of scientific researches on environment[1].

Table 1 Potential PTS released during e-waste dismantling

\begin{tabular}{|c|c|c|}
\hline & pollutant & source \\
\hline \multirow[t]{3}{*}{ dioxin-like pollutants } & $\mathrm{PCDD} / \mathrm{Fs} ; \mathrm{PBDD} / \mathrm{Fs}$ & $\begin{array}{l}\text { incineration of PVC, by-product of incineration of circuit } \\
\text { board }\end{array}$ \\
\hline & $\mathrm{PCBs}$ & insulation oil and heat conducting oil in transformer \\
\hline & PBDEs & brominated flame retardant \\
\hline \multirow[t]{9}{*}{ inorganic pollutants (heavy metals) } & $\mathrm{Cd}$ & $\begin{array}{l}\text { battery, phosphorescent green emitters, cathode ray tube, } \\
\text { printed circuit boards, plastic-curing agent }\end{array}$ \\
\hline & $\mathrm{Cr}$ & coating, hardening agent \\
\hline & $\mathrm{Ba}$ & electronic components \\
\hline & $\mathrm{Pb}$ & $\begin{array}{l}\text { welding, radiation protection, cathode ray tube, printed } \\
\text { circuit boards }\end{array}$ \\
\hline & $\mathrm{Hg}$ & battery, switch, printed circuit boards \\
\hline & $\mathrm{Be}$ & thermal conductors, printed circuit boards, connectors \\
\hline & As & doping agent in transistor, printed circuit boards \\
\hline & $\mathrm{Cu}$ & conductor, printed circuit boards \\
\hline & $\mathrm{Si}$ & glass, cathode ray tube \\
\hline \multirow[t]{7}{*}{ other organic pollutants } & short-chain chlorinated paraffins ( $\mathrm{SCCPs}$ ) & motor, metal sealants \\
\hline & polycyclic aromatic hydrocarbon & by-product of pyrolysis process and insulation \\
\hline & hexabromocyclododecane (HBCD) & brominated flame retardant \\
\hline & dechlorane plus (DP) & chlorinated flame retardant \\
\hline & tetrabromobisphenol A (TBBPA) & brominated flame retardant \\
\hline & $\begin{array}{l}1,2 \text {-bis }(2,4,6 \text { tribromophenoxy) ethane } \\
\text { (BTBPE) }\end{array}$ & brominated flame retardant \\
\hline & decabromo diphenyl ethane (DBDPE) & brominated flame retardant \\
\hline
\end{tabular}


The rapid growth and non-standard dismantling of e-waste have attracted worldwide attention. In February 2002, two environmental organizations from the US West Coast --the Basel Action Network and the Silicon Valley Toxics Coalition -- jointly issued a length report Exporting Harm: The High-Tech Trashing of Asia. With a large number of on-the-site investigations and interviews, the Greenpeace published Anthropological Research Reports on E-Waste Dismantling Industry of Guiyu, Shantou in May 2008. The regional pollution and health risks caused by e-waste dismantling also have caused great attention from worldwide environmental scientists, and papers of e-waste published on the international academic journals have a significant increase from 2000 to 2010 (Figure 1)[1].

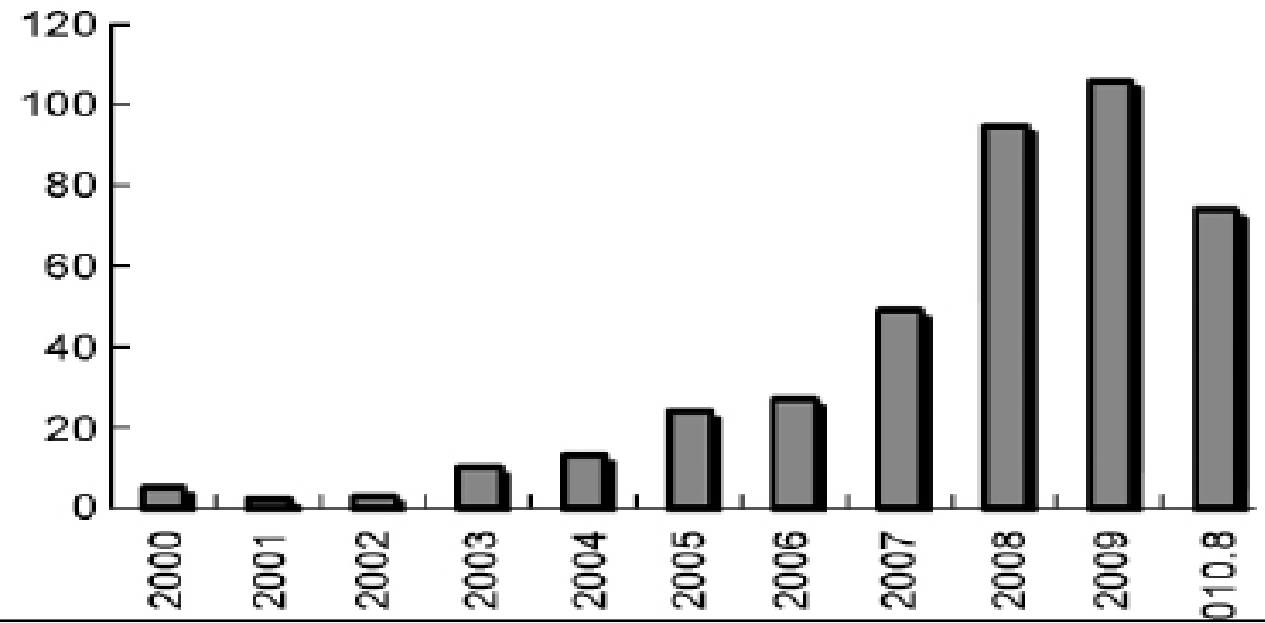

Fig 1 papers with the theme of "e-waste" in last decade(data accessed form ISI Web of knowledge ,2010-8-25

\section{Relevant Policies for the E-Waste Dismantling Industry}

In 1990, China as the first batch of member countries signed the Basel Convention which aimed at controlling the transboundary movements of hazardous waste materials and their disposal. In 1995, China promulgated Prevention Law on Solid Waste Pollution which standardized the recycling of the toxic and hazardous solid waste, including e-waste, and the amendment to this law was passed in 2004. The Ministry of Environmental Protection, the General Administration of Customs and other departments have stated clearly in On Issues Related to Importing the Seventh category of waste that since April 1, 2000, the import of eleven kinds of waste electrical appliances had been banned, including waste TV sets and kinescopes, waste computers, waste displays and electric image tubes, waste duplicators, waste cameras and video recorders and waste household telephones. In June 2000, the Ministry of Environmental Protection reiterated that China would take three measures to crack down on illegal transboundary movements of hazardous waste materials and ban the import of e-waste which will pollute the environment. In February 2003, the EU issued two instructions on the control of hazardous substances contained in electronic products and their waste. Instructions on Waste Electric and Electronic Equipment (Instructions on WEE), and Instructions on the Restriction of Certain Hazardous Substances Used in Electric and Electronic Equipment (Instructions on RoHS), these instructions control these hazardous substances from two aspects of the source and destination.

China issued Procedures for the Control and Prevention of Electronic Information Product Pollution in August 2003, restricting the toxic and hazardous substances contained in electronic products. However, due to ineffective monitoring, local protection, lower illegal costs and many other reasons, every year, there are a large number of e-waste flowing into China through smuggling and other illegal ways for dismantling. In addition, with the development of living standards, China's self-generated electronic waste has also become an important source of e-waste for dismantling areas. From 2005 to 2007, the relevant departments have continuously issued a series of regulations, such as Regulations on Waste Electric and Electronic Product Recycling, Policies of Pollution Prevention Technology for Abandoned Household Appliances and Electronic 
Products, and Regulations on the Pollution Control of Electronic Information Product, and the Ministry of Environmental Protection and the State Council issued Regulations on Environmental Pollution Control of Electronic Waste and Regulations on Recycling of Waste Electric and Electronic Products in 2007 and 2008 respectively, in order to standardize and legalize the recycling of e-waste and related dismantling industry and areas.

\section{The Overview of the Dismantling Activities of E-Waste and the Life of Residents in Dismantling Areas}

According to a report published by UNEP in 2005, 80\% of e-waste around the world had flowed into Asia, with $90 \%$ of e-waste flowed into China. On the other hand, the internal needs of our residents for a variety of electronic products is also increasing year by year, since 2013, China's self-generated electronic waste has reached 1.1 million tons per year, and the growth rate is more than 5\%. Currently, the industry of e-waste dismantling is distributed in the coastal areas, where Guiyu, Guangdong and Taizhou, Zhejiang have become important bases for international electric and electronic waste.

Guiyu which has a total area of about 52 square kilometers is located in the west of Chaoyang District, Shantou City, Guangdong Province. It belongs to the subtropical climate zone, and the annual average temperature is $21.4 \mathrm{C}$, with an average annual rainfall of $1515 \mathrm{~mm}$. The electronic waste dismantling activities have been raised in Guiyu in the early 1990s. Currently, the amount of e-waste and electronic products and plastic recycled in Guiyu have reached 1.55 million tons annually. The division of "junk industry" in the villages of Guiyu is more clear, the villages are divided into plastic villages, metal processing and utilization villages, electronic and circuit board dismantling villages, electric product dismantling villages, and wire and cable dismantling villages, according to the different types of waste for dismantling. Three villages of Huamei, Beiling and Nanyang which are located in the center of Guiyu are the main areas for e- waste dismantling[2], and Longgang, Xianpeng, Xianma, Dutou and other villages are mainly engaged in the waste plastic recycling. If the population of Guiyu is about 150,000 , about $80 \%$ of families has been engaged in the dismantling and recycling industry of waste electric and electronic products as well as reproduced hardware plastic products. In addition, there are about 200,000 migrant workers in Guiyu, almost all of them have involved in the local e-waste industries. Guiyu has formed a relatively complete industrial chain from garbage collection to dismantling, and from the processing to marketing, the output value of this industry accounts for more than $90 \%$ of the gross industry output value in this town, make it become a pillar industry in the local economy and the main source of farmers' income.

\section{Summary and Outlook}

The coexistence of harmfulness and resource is a characteristic of e-waste. Non-standard dismantling activities will lead large quantities of pollutants to be released into the environment, and numerous studies have shown that the environment of e-waste dismantling areas has been polluted seriously, the pollution level of various environmental mediators around the dismantling areas are high, and all kinds of creatures, even the human body, are subject to the direct harm of pollutants, representing certain risks for the local ecosystem, dismantling workers and local residents.

From 2002, the pollution problems caused by the e-waste dismantling has attracted the government and the public's attention, all levels of government departments have made a number of limitations in policies and laws. Besides cracking down on the illegal immigration of e-waste, the problem of e-waste dismantling needs cooperation from other countries' environmental protection departments, especially developed countries'. In addition to the e-waste imported from abroad, our country has become the largest producer of electronic products. With the development of economic, the demand for a variety of electronic products will greatly increase, and all these electronic products will eventually be discarded. Therefore, the management for safe dismantling of 
self-generated e-waste needs to be strengthened when we are cracking down on illegal immigration of e-waste.

\section{References}

[1] P. G. Peng, Y. S. Guo, and J.M. Fu. Progress in Chemistry,2009, 21, 550-557.

[2] D.H. Chen, L.P. Li and X.H. Bi. Environmental Sciences, 2008, (8): 205-210 